\title{
CENTRAL VERTIGO
}

\author{
Sela Pricilia ${ }^{1}$, Shahdevi Nandar Kurniawan ${ }^{2}$ \\ ${ }^{I}$ Doctor Profession Study Program, Medical Faculty, Brawijaya University, Saiful Anwar General Hospital, Malang, Indonesia \\ ${ }^{2}$ Neurology Department, Medical Faculty, Brawijaya University, Saiful Anwar General Hospital, Malang, Indonesia
}

Correspondence : shahdevinandar@ub.ac.id

\begin{abstract}
Central vertigo is a symptom characterized by a feeling of changes in body position or environment as a result of diseases originating from the central nervous system. Central vertigo is caused by a disease that extend from vestibular nuclei in medulla oblongata to ocular motor nuclei and integration system in mesencephalon to vestibulocerebellum, thalamus and vestibular cortex in temporoparietal and the neuronal pathway which mediate VOR (vestibulo-ocular reflex). The diseases can be vestibular migrain, TIA (Transient Ischemic Attack), Vertebrobasilar ischemic stroke, multiple sclerosis, tumor in cerebelopontine angle and congenital malformation like Dandy Walker Syndrome. Central vertigo can be diagnosed by performing several special tests. This examination can also distinguish central vertigo from its differential diagnosis, namely peripheral vertigo. Management of central vertigo can be in the form of acute attack management and specific management according to the cause.
\end{abstract}

Keyword : Central vertigo, central nervous system, vestibulo-ocular reflex, VOR.

\section{PENDAHULUAN}

Vertigo adalah suatu gejala yang ditandai dengan adanya perasaan perubahan posisi dari tubuh atau posisi dari lingkungan sekitar. Berdasarkan lokasi penyebabnya, vertigo dibedakan menjadi vertigo sentral dan perifer. Vertigo sentral adalah vertigo yang disebabkan oleh penyakit yang berasal dari sistem saraf pusat (1). Vertigo sentral diakibatkan oleh lesi di sepanjang nukleus vestibular di medulla oblongata hingga ocular motor nuclei dan pusat integrasi di mesensefalon hingga vestibulocerebellum, thalamus dan korteks vestibular di temporoparietal. Pasien dengan vertigo sentral biasanya mengeluhkan penurunan fungsi penglihatan, persepsi dan gejala postural yang mana gejala ini dapat menjadi petunjuk letak lesi di batang otak (2). Penyebab dari vertigo sentral bisa bermacam-macam. Beberapa di antaranya adalah migrain vestibular, stroke iskemik vertebrobasilar, TIA (Transient Ischemic Attack), multiple sclerosis, atau tumor yang terletak di sudut cerebellopontine dan kelainan kongenital seperti Dandy Walker Syndrome $(1,3,15)$.

\section{DEFINISI}

Vertigo adalah sebuah ilusi di mana pasien merasa tubuh dan/atau lingkungannya berputar. Vertigo dibedakan menjadi dua berdasarkan letak lesi penyebabnya. Vertigo sentral adalah vertigo yang disebabkan oleh lesi sentral yang dapat disertai gejala unilateral atau hanya dirasakan di satu sisi tubuh pasien (4).
Lesi sentral yang dimaksud adalah lesi di sepanjang jalur vestibular di batang otak. Jalur ini membentang dari nukleus vestibular di medulla oblongata hingga ke korteks temporoparietal. Struktur terpenting dalam terbentuknya vertigo sentral adalah jalur neuronal yang memediasi VOR (Vestibulo-ocular reflex). Jalur ini berjalan dari labirin perifer di atas nukleus vestibular di batang otak menuju ke nukleus motorik okuler (III, IV dan VI) dan pusat integrasi supranukleus di pons dan mesensefalon (nukleus intersisial Cajal, INC dan nukleus intersisial dari fasikulus longitudinal medialis (riMLF)). Pergerakan mata dibentuk dari tiga lengkung refleks ini ketika ada pergerakan cepat dari kepala dan tubuh (2).

Berdasarkan jalur lengkung refleks yang dibentuk, terdapat jalur asenden dan desenden. Jalur asenden berjalan secara kontralateral dan ipsilateral di atas thalamus posterolateral hingga ke area korteks temporoparietal dan insula. Korteks vestibular parietoinsular dan area di girus temporalis superior serta inferior lobus parietal adalah area yang bertanggung jawab terhadap persepsi, self-motion, dan orientasi tempat (2).

Jalur desenden VOR berjalan melalui nukleus vestibularis sepanjang traktus vestibulospinal medialis dan lateralis menuju medula spinalis untuk memediasi kontrol postur tubuh (2).

\section{Article History}

Received: January 25, 2021; Accepted: February 17, 2021; Published: March 1, 2021

Cite As:

Pricilia S, Kurniawan SN. Central vertigo. Journal of Pain, Vertigo and Headache; 2021.2:38- 


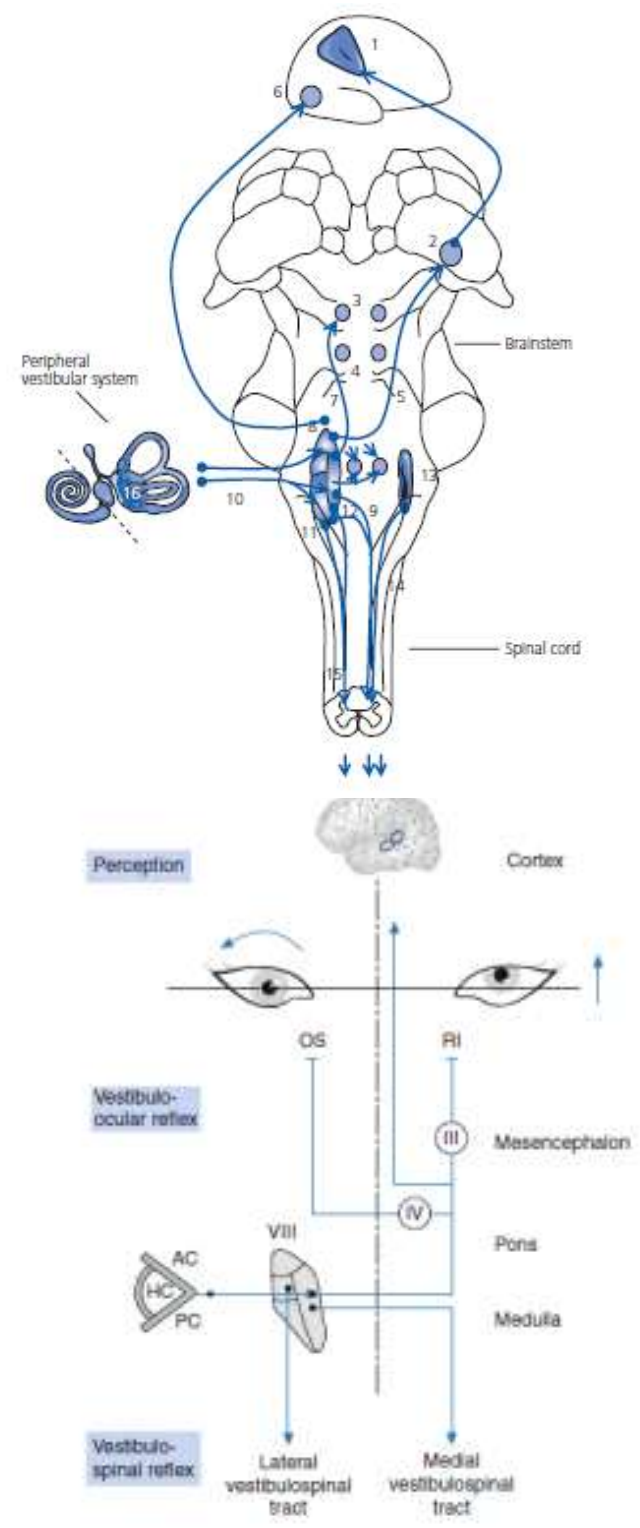

Gambar 1. Sistem Vestibular Sentral dan VOR $(2,11)$.

\section{EPIDEMIOLOGI}

Vertigo dialami oleh $20-30 \%$ orang dewasa di usia produktif. Sekitar $7-10 \%$ vertigo yang dialami ini bersifat rekuren. Vertigo juga dapat dialami oleh anak-anak dengan prevalensi 8-18\% (5). Pada penelitian yang dilakukan di tahun 2015 di Amerika, insidensi dari vertigo berkisar di angka $3.1 \%$ di mana prevalensinya sebesar $22.9 \%$ (1). Insidensi vertigo akan meningkat seiring bertambahnya usia dan sedikit lebih sering dialami oleh laki-laki. Vertigo yang disebabkan oleh penyakit di sistem saraf pusat memiliki prevalensi 3.2-12.5\% dari keseluruhan pasien yang datang ke UGD (6). Dari semua pasien yang datang ke UGD dengan vertigo, sebanyak $4 \%$ disebabkan oleh karena penyakit di serebelum, $1.3 \%$ penyakit di fossa posterior, dan $14.7 \%$ disebabkan oleh penyakit jantung dan metabolik (7).

\section{ETIOLOGI}

Etiologi dari vertigo sentral seperti yang sudah disebutkan sebelumnya adalah adanya lesi atau penyakit di sistem saraf pusat. Penyakit ini meliputi migrain vestibular, stroke iskemik vertebrobasilar, TIA (Transient Ischemic Attack), sklerosis multipel, dan adanya massa pada sudut serebelopontin seperti neuroma akustik dan tumor $(1,3)$. Selain itu, vertigo sentral juga bisa disebabkan oleh penyakit kongenital seperti Dandy Walker Syndrome yang merupakan kelainan berupa hipoplasi vermis serebelum, dilatasi kistik ventrikel ke empat, dan pembesaran fossa posterior baik disertai ataupun tanpa disertai hidrosefalus (15).

\section{PATOFISIOLOGI}

Lesi unilateral pada jalur vestibular akan menyebabkan terjadinya sindroma vestibular sebagai konsekuensi dari ketidakseimbangan tonus. Ada dua macam sindrom klinis yang relevan yaitu spatial hemineglect dan the pusher syndrome yang terjadi apabila lesi terdapat di daerah thalamus atau di hemisfer otak. Sindroma ini biasanya didapati pada pasien stroke. Spatial hemineglect terjadi apabila terdapat gangguan atau kerusakan di bagian otak yang bertanggung jawab atas orientasi ruang. Hal ini akan menyebabkan pasien tidak dapat mempersepsikan objek di salah satu sisi. The pusher syndrome adalah sebuah gejala yang biasanya ditemui pada pasien post-stroke di mana pasien akan cenderung memposisikan badannya ke arah tubuh yang mengalami kelemahan. Pada sindroma ini terjadi salah persepsi pada impuls yang disalurkan. Pasien dengan sindroma ini juga memiliki gangguan pada persepsi visual, proprioseptif dan pergerakan motorik sehingga menyulitkan mereka untuk memahami postur dan keseimbangan tubuhnya. Kondisi ini merefleksikan disfungsi dari orientasi ruang, atensi dan kontrol postur tubuh. Penyakit yang melibatkan fungsi vestibular sentral ini tidak hanya melibatkan konvergensi input multisensor tetapi juga integrasi sensorimotor dengan memori spasial, orientasi, atensi, navigasi dan interaksi tubuh dan lingkungan ketika bergerak (2).

Ketika ada kerusakan atau gangguan pada otak yang berfungsi mempersepsikan impuls terkait keseimbangan ini, maka respon yang terbentuk tentu tidak akan normal. Perubahan posisi dan gerak kepala yang diinformasikan melalui sistem vestibular normalnya akan membuat mata tetap stabil ketika memandang. Hal ini yang mana telah disebutkan sebelumnya yaitu dengan mekanisme VOR. Apabila terdapat gangguan pada salah satu komponen VOR misalnya batang otak maka impuls yang diteruskan akan salah dipersepsikan. Akibatnya pasien akan mengalami vertigo yang disertai dengan nistagmus dan ketidakseimbangan postur tubuh.

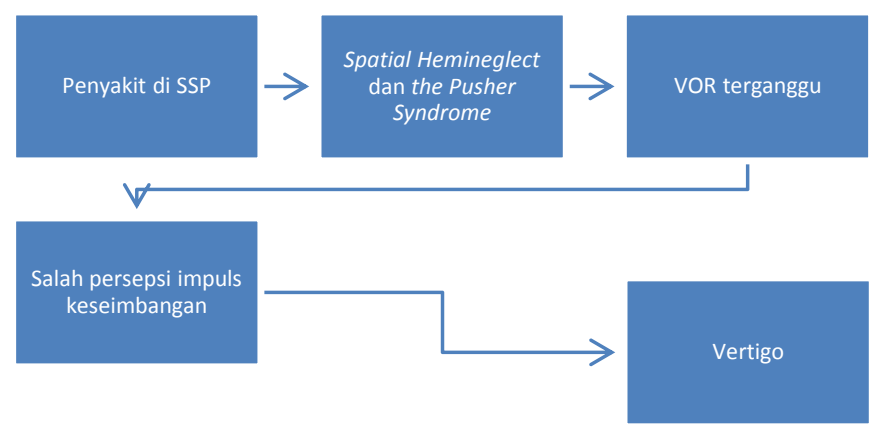

Gambar 2. Patofisiologi Vertigo Sentral $(2,8)$. 
Tabel 1. Durasi Vertigo dan Hubungan dengan Penyebabnya (2)

\begin{tabular}{|c|c|}
\hline Durasi Vertigo & Lokasi Lesi dan Penyebab \\
\hline $\begin{array}{lcr}\text { Vertigo } & \text { bertahan } & \text { selama } \\
\text { beberapa } & \text { detik } & \text { sampai } \\
\text { beberapa jam } & \end{array}$ & $\begin{array}{l}\text { TIA di area vertebrobasilar } \\
\text { Migrain vestibular } \\
\text { Serangan paroksismal batang otak } \\
\text { dengan disertai ataksia atau } \\
\text { disartria pada medulla spinalis } \\
\text { Epilepsi vestibular }\end{array}$ \\
\hline $\begin{array}{lcr}\text { Vertigo bertahan } & \text { selama } \\
\text { beberapa jam } & \text { sampai } \\
\text { beberapa hari } & \end{array}$ & $\begin{array}{l}\text { Infark, perdarahan, atau plak di } \\
\text { medulla spinalis batang otak } \\
\text { Serangan jangka lama migrain } \\
\text { vestibular }\end{array}$ \\
\hline $\begin{array}{lcc}\text { Vertigo } & \text { bertahan } & \text { selama } \\
\text { beberapa } & \text { hari } & \text { sampai } \\
\text { beberapa minggu } & \end{array}$ & $\begin{array}{l}\text { Penyakit degeneratif serebelum } \\
\text { Kerusakan pontomedula } \\
\text { paramedian atau } \\
\text { pontomesensefalik karena infark, } \\
\text { perdarahan, tumor atau intoksikasi. }\end{array}$ \\
\hline
\end{tabular}

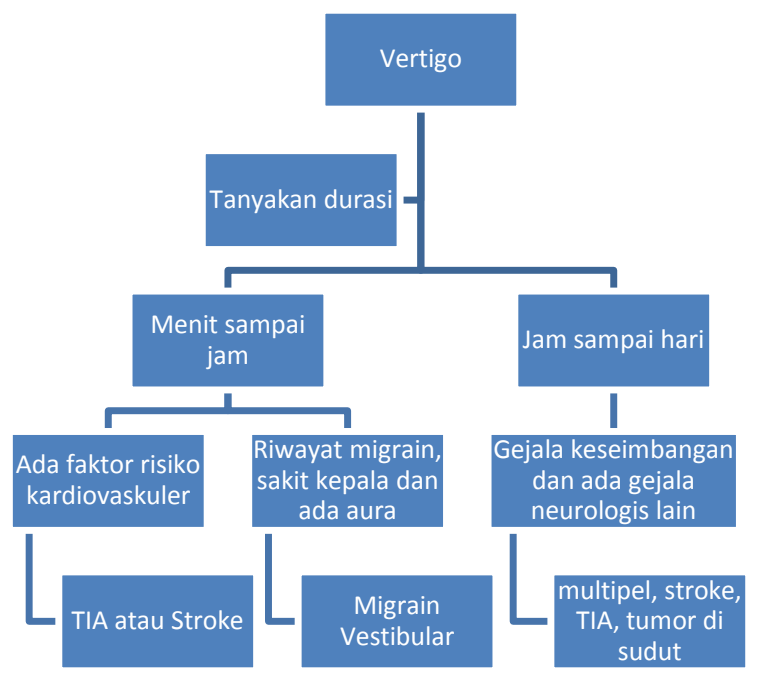

Gambar 3. Algoritma Anamnesis Vertigo (9).

\section{DIAGNOSIS}

Diagnosis pada vertigo sentral dapat ditegakkan dengan anamnesis dan pemeriksaan fisik. Pada anamnesis harus ditanyakan apakah pusing yang dirasakan oleh pasien terasa seperti berputar atau hanya merasa kepalanya ringan. Selanjutnya perlu ditanyakan juga durasi, onset, frekuensi, keparahan dan faktor yang memperberat vertigonya. Biasanya, vertigo sentral durasinya lebih lama tetapi tingkat keparahannya tergolong ringan. Gejala lain yang berhubungan dengan vertigo juga harus dieksplorasi seperti mual muntah, sakit kepala, penurunan pendengaran, telinga terasa penuh dan tinnitus. Riwayat penyakit juga perlu ditanyakan karena adanya risiko penyakit jantung meningkatkan kejadian iskemia cerebrovaskular dan dapat menyebabkan vertigo khususnya di usia tua dengan serangan spontan (9).

\section{PEMERIKSAAN KHUSUS}

Pemeriksaan yang dilakukan untuk membantu penegakan diagnosis vertigo sentral disingkat dengan HINTS yang memiliki kepanjangan Head Impulse, Nystagmus dan Test of Skew. Pemeriksaan yang pertama adalah horizontal head impulse. Pemeriksaan ini dilakukan dengan menginstruksikan pasien untuk melihat ke arah hidung pemeriksa dan

\section{MANIFESTASI KLINIS}

Tabel 2. Manifestasi Klinis Vertigo Sentral Berdasarkan Penyebabnya $(1,3,15)$

\begin{tabular}{|c|c|}
\hline $\begin{array}{l}\text { Penyebab } \\
\text { Vertigo Sentral }\end{array}$ & Manifestasi Klinis \\
\hline Migrain vestibular & $\begin{array}{l}\text { - Sakit kepala parah } \\
\text { - Mual } \\
\text { - Fotofobia } \\
\text { - Phonophobia } \\
\text { - Sensitif terhadap pergerakan kepala } \\
\text { - Apabila disertai aura maka bisa didapatkan } \\
\text { scotoma, perubahan somatosensoris, halusinasi } \\
\text { auditorik dan olfaktori, kelemahan badan, } \\
\text { kesulitan bicara, dan pusing. Aura dapat bertahan } \\
\text { selama beberapa detik sampai beberapa jam. Aura } \\
\text { dapat muncul sebelum, setelah atau bersamaan } \\
\text { dengan sakit kepala. }\end{array}$ \\
\hline \multirow{3}{*}{$\begin{array}{l}\text { Stroke Iskemik } \\
\text { Vertebrobasilar }\end{array}$} & $\begin{array}{l}\text { Oklusi arteri serebelar posterior inferior } \\
\text { - Lateral medullary syndrome (Wallenberg's } \\
\text { syndrome) : vertigo, nystagmus, gangguan } \\
\text { berjalan, ataksia ipsilateral, nyeri atau mati rasa } \\
\text { pada wajah, hemianestesia, Horner's syndrome, } \\
\text { dysphagia, suara serak, dan paralisis nervus } \\
\text { facialis. }\end{array}$ \\
\hline & $\begin{array}{l}\text { Oklusi arteri serebelar anterior inferior } \\
\text { - Lateral pontine syndrome : gejalanya mirip } \\
\text { dengan Wallenberg's Syndrome tetapi ditambah } \\
\text { dengan adanya keterlibatan nervus VII dan VIII } \\
\text { sehingga ada gejala paralisis wajah ipsilateral, } \\
\text { tinnitus, dan penurunan pendengaran. }\end{array}$ \\
\hline & $\begin{array}{l}\text { Oklusi Arteri Serebelar Superior } \\
\text { - Lateral superior pontine syndrome : vertigo, } \\
\text { nystagmus, gangguan berjalan, ataksia ipsilateral, } \\
\text { mati rasa wajah, hemianastesia tubuh } \\
\text { kontralateral, dan Horner's syndrome. }\end{array}$ \\
\hline TIA & $\begin{array}{l}\text { - Vertigo adalah satu-satunya gejala. } \\
\text { - Gejala menghilang dalam } 24 \text { jam }\end{array}$ \\
\hline Sklerosis Multipel & $\begin{array}{l}\text { - Pusing } \\
\text { - Gangguan berjalan dan keseimbangan } \\
\text { - Keterlibatan saraf VIII } \\
\text { - Internuclear opthalmoplegia, pandangan kabur, } \\
\text { dan diplopia traien. }\end{array}$ \\
\hline $\begin{array}{l}\text { Massa di sudut } \\
\text { serebelopontin }\end{array}$ & $\begin{array}{l}\text { - Gejala keseimbangan } \\
\text { - Tinnitus unilateral } \\
\text { - Penurunan pendengaran unilateral yang ringan } \\
\text { - Mati rasa, nyeri wajah, trigeminal neuralgia } \\
\text { - Sakit kepala } \\
\text { - Penurunan penglihatan } \\
\text { - Ataksia } \\
\text { - Hemiparesis } \\
\text { - Gagal nafas } \\
\text { - Hidrosefalus }\end{array}$ \\
\hline $\begin{array}{l}\text { Dandy Walker } \\
\text { Syndrome }\end{array}$ & $\begin{array}{l}\text { Gejala bergantung pada kelainan anatomi yang } \\
\text { mendasari serta usia saat manifestasi muncul. } \\
\text { Umumnya berupa : } \\
\text { - Hidrosefalus } \\
\text { - Kejang } \\
\text { - Letargi } \\
\text { - Nyeri kepala } \\
\text { - Sinkop } \\
\text { - Ataksia, disequilibrium dan nistagmus } \\
\text { - Trigeminal neuralgia } \\
\text { - Gangguan psikotik }\end{array}$ \\
\hline
\end{tabular}
pemeriksa dengan cepat memutar kepala pasien dengan kecepatan sedang sambil mengamati mata pasien. Adanya gerakan sakadik refiksasi didefinisikan sebagai hasil positif. Apabila hasilnya normal maka vertigonya adalah tipe sentral. Head impulse test memiliki angka sensitivitas sebesar $11.1 \%$ dan spesifisitas sebesar $100 \%$ dalam membedakan central vestibular disorder dengan vestibular migraine (6). 
Pemeriksaan selanjutnya adalah pemeriksaan nistagmus. Pemeriksaan ini dilakukan dengan manuver Dix-Hallpike. Pasien diputar kepalanya 45 derajat ke satu sisi kemudian pasien diminta berbaring dengan kepala menggantung yang ditumpu dengan tangannya. Pemeriksa memperhatikan nistagmus pada mata pasien dan menanyakan apakah pasien merasa pusing. Posisi ini dipertahankan selama 30 detik atau bisa selama 1 menit apabila tidak ada respon. Hasilnya dikatakan positif apabila pasien mengeluh pusing dan didapatkan nistagmus (9). Pada pemeriksaan nistagmus, apabila disebabkan oleh vertigo sentral maka arah nistagmusnya adalah horizontal, pure torsional atau pure vertical, ada perubahan arah, dapat berubah arah dengan konvergensi, dapat berubah arah atau intensitas dengan perubahan posisi kepala atau mata (10).

Selanjutnya adalah test of skew, di mana pemeriksaan ini dilakukan dengan meminta pasien melihat ke arah hidung pemeriksa. Lalu, kedua mata pasien kanan dan kiri ditutup secara bergantian dengan cepat. Kemudian diamati apakah mata pasien bergerak untuk kembali sejajar lagi. Apabila hasilnya ada ketidaksejajaran vertikal pada mata maka mengindikasikan adanya vertigo sentral (6).

Selain itu juga dapat dilakukan pemeriksaan lain seperti tes Romberg. Tes Romberg ini dikatakan positif apabila pasien dapat mempertahankan keseimbangannya dalam mata terbuka. Ketika tes ini dilakukan dan pasien jatuh ke satu sisi baik dengan mata terbuka maupun tertutup maka kelainannya dapat dipastikan berada di serebelum (9).

Apabila gejala lebih sugestif mengarah pada vertigo sentral, maka pemeriksaan neurologis perlu dilakukan. Tanda-tanda disfungsi serebelum seperti disdiadokinesia, dismetria, disartria dan ataksia harus dieksplorasi (9).

\section{PEMERIKSAAN PENUNJANG}

Pemeriksaan penunjang yang dapat dilakukan untuk membantu penegakan diagnosis vertigo sentral adalah pemeriksaan pendengaran (audiological testing). Pemeriksaan ini dapat mengetahui ada tidaknya penurunan fungsi pendengaran pada pasien dengan vertigo. Selain itu, bisa juga dilakukan caloric testing untuk mengevaluasi fungsi dari labirin untuk membantu membedakan vertigo yang terjadi termasuk tipe perifer atau sentral. Pemeriksaan radiologis merupakan alat investigasi yang penting apabila didapatkan kecurigaan penyebab vertigo adalah di sentral. Gejala klinis seperti vertigo yang terjadi tiba-tiba dan tidak diprovokasi oleh perubahan posisi, berhubungan dengan sakit kepala baru di daerah oksipital, berhubungan dengan ketulian tetapi tidak ada riwayat Meniere disease, vertigo akut dengan head impulse test normal, dan berhubungan dengan tanda neurologis sentral seperti ataksia trunkal merupakan pertimbangan untuk segera dilakukan pemeriksaan radiologis. MRI lebih direkomendasikan ketika pasien memiliki kecurigaan penyakit seperti sklerosis multipel, infark vaskular, atau tumor di serebelopontin. CT-scan lebih direkomendasikan untuk mendeteksi adanya abnormalitas tulang petrosa atau perdarahan serebelum dan sebagai alat untuk follow up vertigo yang diinduksi trauma (9).

\section{DIAGNOSIS BANDING}

Tabel 3. Diagnosis Banding Vertigo Sentral $(11,14)$.

\begin{tabular}{|c|c|}
\hline Penyakit & Karakteristik \\
\hline $\begin{array}{l}\text { Benign } \\
\text { Paroxysmal } \\
\text { Positional } \\
\text { Vertigo (BPPV) }\end{array}$ & $\begin{array}{l}\text { - Vertigo yang diperberat dengan perubahan kepala } \\
\text { di posisi tertentu. } \\
\text { - Tidak ada penurunan pendengaran dan tinnitus. } \\
\text { - Mual dan muntah } \\
\text { - Didapatkan nistagmus pada Dix-Hallpike } \\
\text { maneuvre }\end{array}$ \\
\hline $\begin{array}{l}\text { Multilevel } \\
\text { vestibulopathy }\end{array}$ & $\begin{array}{l}\text { - Biasanya didapatkan pada usia lanjut. } \\
\text { - Disebabkan karena mobilitasnya yang sudah } \\
\text { terbatas, masalah neurologis, TIA/stroke, diabetes, } \\
\text { polifarmasi dan penglihatan yang buruk. }\end{array}$ \\
\hline Cholesteatoma & $\begin{array}{l}\text { - Keluar cairan dari telinga } \\
\text { - Penurunan fungsi pendengaran } \\
\text { - Vertigo } \\
\text { - Tidak seimbang ketika ada perubahan cepat dari } \\
\text { - Fosisi kepala } \\
\text { - Heala test positif } \\
\text { - Head shast testing : clear catch up saccades } \\
\text { - Unterberger test : rotasi ke arah yang mengalami } \\
\text { cholesteatoma }\end{array}$ \\
\hline $\begin{array}{l}\text { Meniere's } \\
\text { disease }\end{array}$ & $\begin{array}{l}\text { - Vertigo spontan } \geq 2 \text { kali selama }>20 \text { menit } \\
\text { - Tuli sensorineural } \\
\text { - Aura bisa berupa penurunan pendengaran, tinnitus, } \\
\text { atau aural pressure. } \\
\text { - Serangan Meniere's disease bersifat akut dan } \\
\text { episodik (6-11 kali per tahun). } \\
\text { - Stage } 1 \text { : vertigo, fungsi pendengaran berfluktuasi } \\
\text { tetapi kembali normal setelah serangan, tinnitus } \\
\text { dan aural pressure menghilang setelah serangan, } \\
\text { hasil tes keseimbangan dan fungsi pendengaran } \\
\text { normal. } \\
\text { - Stage } 2 \text { : vertigo berulang, pendengaran } \\
\text { berfluktuasi tetapi tidak dapat kembali normal, } \\
\text { tinnitus dan aural pressure tidak menghilang } \\
\text { sepenuhnya setelah serangan. } \\
\text { - Stage } 3 \text { : Tumarin drop attack yaitu pasien tiba- } \\
\text { tiba jatuh tanpa kehilangan kesadaran dan tanpa } \\
\text { gejala neurologis, fungsi pendengaran buruk, } \\
\text { tinnitus dan aural pressure persisten. }\end{array}$ \\
\hline $\begin{array}{l}\text { Superior } \\
\text { semicircular } \\
\text { canal } \\
\text { dehiscence }\end{array}$ & $\begin{array}{l}\text { - Tuli konduksi } \\
\text { - Telinga terasa penuh } \\
\text { - Tinnitus } \\
\text { - Merasa mendengar langkah kakinya sendiri atau } \\
\text { pergerakan sendi atau pergerakan mata di telinga } \\
\text { - yang mengalami gangguan. } \\
\text { - Vertigo yang diinduksi suara atau vertigo } \\
\text { posisional } \\
\text { - Henebert's sign : elicit nystagmus dengan } \\
\text { penekanan pada tragus } \\
\text { - Tullio phenomenon : elicit nystagmus apabila } \\
\text { mendengar suara yang keras } \\
\text { - Nystagmus ketika dilakukan valsava maneuvre }\end{array}$ \\
\hline $\begin{array}{l}\text { Vestibular } \\
\text { schwannoma }\end{array}$ & $\begin{array}{l}\text { - Penurunan fungsi pendengaran yang progresif } \\
\text { - Tinnitus } \\
\text { - Gangguan keseimbangan } \\
\text { - Vertigo } \\
\text { - Ataksia } \\
\text { - Hitselberger's sign : penurunan sensasi pada kulit } \\
\text { kanalis auditorius eksternal posterior } \\
\text { - Parastesia pada distribusi saraf trigeminal } \\
\text { - Untebergers's test : rotasi ke sisi tumor }\end{array}$ \\
\hline $\begin{array}{l}\text { Perilymph } \\
\text { fistula }\end{array}$ & $\begin{array}{l}\text { - Penurunan fungsi pendengaran tiba-tiba } \\
\text { - Tinnitus } \\
\text { - Telinga terasa penuh } \\
\text { - Vertigo akut atau kronik } \\
\text { - Gangguan keseimbangan persisten } \\
\text { - Fistula test positif } \\
\text { - Eye-close- turning test positif }\end{array}$ \\
\hline
\end{tabular}




\section{TATALAKSANA}

\section{Tatalaksana Serangan Akut Vertigo}

Serangan akut vertigo terlepas dari apapun penyebabnya, akan menghilang sendiri dalam 24-48 jam karena ada efek kompensasi dari batang otak. Selama fase akut, terapi suportif seperti tirah baring dan pemberian vestibular blocking agents dapat mengurangi gejala yang terjadi. Kombinasi dari antihistamin dan antiemetik adalah obat yang sering digunakan (12).

Tabel 4. Terapi Farmakologis Serangan Akut Vertigo (12).

\begin{tabular}{|c|c|c|}
\hline \multirow{3}{*}{ Antihistamin } & cking Agents & Dosis \\
\hline & Promethazine & $\begin{array}{c}12.5-25 \mathrm{mg} \text { per } \\
\text { oral, IM atau } \\
\text { per rektal tiap } \\
\text { 4-12 jam }\end{array}$ \\
\hline & Betahistine & $\begin{array}{c}\text { 4-16 mg tiap } 8 \\
\text { jam per hari }\end{array}$ \\
\hline \multirow{2}{*}{ Benzodiazepine } & Diazepam & $\begin{array}{l}2-10 \mathrm{mg} \text { per } \\
\text { oral atau IV } \\
\text { tiap 4-8 jam }\end{array}$ \\
\hline & Lorazepam & $\begin{array}{l}0.5-2 \mathrm{mg} \text { per } \\
\text { oral, IM, atau } \\
\text { IV tiap 4-8 jam }\end{array}$ \\
\hline \multirow[t]{2}{*}{ Antiemetik } & Prochlorperazine & $\begin{array}{c}5-10 \mathrm{mg} \text { per } \\
\text { oral atau IM } \\
\text { tiap 6-8 jam } \\
\text { atau } 25 \mathrm{mg} \text { per } \\
\text { rektal tiap } 12 \\
\text { jam }\end{array}$ \\
\hline & Metoclopramide & $\begin{array}{l}10-20 \mathrm{mg} \text { per } \\
\text { oral tiap } 6 \text { jam } \\
\text { atau } 10-20 \mathrm{mg} \\
\text { IV perlahan } \\
\text { tiap } 6-8 \text { jam }\end{array}$ \\
\hline
\end{tabular}

\section{Tatalaksana Spesifik Sesuai Penyebab}

Penyebab vertigo sentral yang berbahaya adalah TIA atau stroke. Kondisi ini umum terjadi khususnya pada pasien yang memiliki faktor risiko kardiovaskular. Manajemen yang dapat dilakukan adalah melakukan rujukan ke rumah sakit dengan segera dan melakukan pemeriksaan radiologis. Modifikasi faktor risiko kardiovaskular dan terapi antikoagulan dapat membantu mencegah komplikasi lebih lanjut (12). Untuk mengatasi vertigo yang disebabkan oleh migrain vestibular dapat diberikan profilaksis migrain yaitu agonis reseptor serotonin (obat golongan Triptan) (1). Apabila penyebabnya berupa tumor atau kelainan seperti Dandy Walker Syndrome maka tindakan operatif dapat dipertimbangkan (15).

Pada vertigo juga dapat dilakukan rehabilitasi untuk mengatasi intolerasi gerak dan masalah keseimbangan pada pasien apabila penyakit yang mendasari sudah tidak menimbulkan masalah. Tujuan dari rehabilitasi ini adalah meningkatkan stabilitas gaze, meningkatkan stabilitas postur tubuh, mencegah vertigo, dan meningkatkan kemampuan pasien dalam melakukan aktivitas sehari-hari. Rehabilitasi ini memfasilitasi perbaikan dari mekanisme keseimbangan yang meliputi adaptasi, substitusi, somatosensorik dan strategi postural (13).
Tabel 4. Terapi Farmakologis Serangan Akut Vertigo (12).

\begin{tabular}{|c|c|}
\hline $\begin{array}{l}\text { Posisi Pasien saat } \\
\text { Rehabilitasi }\end{array}$ & Kegiatan \\
\hline Di kasur atau duduk & $\begin{array}{l}\text { Pergerakan mata (lambat } \\
\text { kemudian dipercepat) : atas } \\
\text { bawah, ke samping dan } \\
\text { memfokuskan ke jari-jari. } \\
\text { - Pergerakan kepala (lambat } \\
\text { kemudian cepat dilanjutkan } \\
\text { dengan mata tertutup) : } \\
\text { menunduk ke depan dan } \\
\text { menengadah, berputar dari satu } \\
\text { sisi ke sisi lain. }\end{array}$ \\
\hline Duduk & $\begin{array}{ll}\text { - } & \text { Pergerakan mata dan kepala } \\
\text { - } & \text { Mengangkat dan memutar bahu } \\
\text { - } & \text { Membungkuk dan mengambil } \\
& \text { objek dari lantai. } \\
\end{array}$ \\
\hline Berdiri & $\begin{array}{l}\text { Pergerakan mata, kepala dan } \\
\text { bahu } \\
\text { - Merubah posisi dari duduk ke } \\
\text { berdiri dengan mata terbuka dan } \\
\text { tertutup } \\
\text { - Melempar bola kecil dari satu } \\
\text { tangan ke tangan lain } \\
\text { - Melempar bola dari tangan ke } \\
\text { tangan di bawah lutut } \\
\text { - Merubah posisi dari duduk ke } \\
\text { berdiri dan berputar. }\end{array}$ \\
\hline Bergerak & $\begin{array}{l}\text { Memutari seseorang yang akan } \\
\text { melempar bola } \\
\text { - Berjalan di ruangan dengan mata } \\
\text { terbuka dan tertutup } \\
\text { - Berjalan naik turun dengan mata } \\
\text { terbuka dan tertutup } \\
\text { - Permainan seperti bowling dan } \\
\text { basket. }\end{array}$ \\
\hline
\end{tabular}

\section{PROGNOSIS}

Pasien dengan vertigo sentral umumnya memiliki prognosis yang baik selama penyakit penyebabnya bisa dikendalikan salah satunya dengan modifikasi faktor risiko dan rutin mengonsumsi obat. Vertigo sentral yang disebabkan oleh TIA atau stroke lebih berbahaya dan apabila tidak dilakukan penanganan dengan segera akan berdampak buruk pada pasien. Pada pasien yang melakukan rehabilitasi keseimbangan dengan teratur akan terbentuk perbaikan yang signifikan pada keseimbangan tubuh dan pandangan mata (12).

\section{KESIMPULAN}

Vertigo sentral merupakan suatu kelainan yang disebabkan karena penyakit di sistem saraf pusat salah satunya adalah TIA dan stroke. Angka kejadiannya meningkat seiring bertambahnya usia. Penegakan diagnosis vertigo sentral dilakukan dengan melakukan anamnesis terkait gejala dan riwayat penyakit pasien serta dengan melakukan pemeriksaan HINTS. Apabila ada indikasi dapat pula dilakukan pemeriksaan radiologis untuk menunjang diagnosis. Tatalaksana yang diberikan dapat berupa tatalaksana serangan akut dan spesifik. Pada serangan akut dapat diberikan vestibular blocking agents. Terapi spesifik 
disesuaikan dengan penyebab vertigo sentral. Terapi rehabilitasi juga dapat dilakukan untuk memperbaiki fungsi keseimbangan dan stabilisasi pandangan mata pada pasien serta mencegah rekurensi vertigo di masa yang akan datang.

\section{DAFTAR PUSTAKA}

1. Gnerre, P, Casati C, Frualdo M., Cavalleri M, \& Guizzetti S. Management of vertigo: From evidence to clinical practice. Italian Journal of Medicine; 2015. 9(2), 180-192. DOI:

2. Brandt $\mathrm{T}$, \& DIeterich M. The dizzy patient: Don't forget disorders of the central vestibular system. Nature Reviews Neurology; 2017. 13(6):352-362. DOI: https://doi.org/10.1038/nrneurol.2017.58

3. Thompson TL, \& Amedee R. Vertigo: A review of common peripheral and central vestibular disorders. Ochsner Journal; 2009. 9(1), 20-26. Avalaible from: https://www.ncbi.nlm.nih.gov/pmc/articles/PMC30962 43/

4. Sunitha M, Asokan L, \& Sambandan AP. Vertigo: Incidences, diagnosis and its relations with hearing loss. Indian Journal of Otolaryngology and Head and Neck Surgery; 2019. 71:1282-1286.

DOI: https://doi.org/10.1007/s12070-018-1315-6

5. Fedorowicz JP, Bielińska M, \& Olszewski J. Posturography studies in patients with central and mixed vertigo summary. Otolaryngologia Polska; 2018. 72(3):6-11.

DOI: https://doi.org/10.5604/01.3001.0011.7256

6. Quimby AE, Kwok ESH, Lelli D, Johns P, \& Tse D. (2018). Usage of the HINTS exam and neuroimaging in the assessment of peripheral vertigo in the emergency department. Journal of Otolaryngology - Head and Neck Surgery; 2018. 47(1):1-9.
DOI: https://doi.org/10.1186/s40463-018-0305-8

7. Das S, Chakraborty S, \& Shekar S. Dizziness in a tertiary care centre in sikkim: Our experience and limitations. Indian Journal of Otolaryngology and Head and Neck Surgery; 2017. 69(4):443-448.

DOI: https://doi.org/10.1007/s12070-017-1221-3

8. Eber AM. La rééducation des vertigineux. In Revue du Praticien; 1994. Vol. 44, Issue 3.

9. Kuo CH, Pang L, \& Chang R. Vertigo: Part 1 Assessment in general practice. Australian Family Physician; 2008. 37(5), 341-347. DOI:

10. Bronsteiin Adolfo. Oxford Textbook of Vertigo and Imbalance; 2013. DOI: $10.1093 / \mathrm{med} / 9780199608997.001 .0001$

11. Kanegaonkar R, \& Tysome J. Dizziness and Vertigo: an Introduction and Practical Guide; 2014.

12. Kuo CH, Pang L, \& Chang R. Vertigo: Part 2 Management in general practice. Australian Family Physician; 2008. 37(6), 409-413. Avalaible from: https://pubmed.ncbi.nlm.nih.gov/18523693/

13. Alpini DC, Cesarani A, \& Brugnoni G. Vertigo rehabilitation protocols. In Vertigo Rehabilitation Protocols. DOI: https://doi.org/10.1007/978-3-31905482-7

14. Millennie HE, Munir B, Afif Z, Damayanti R, \& Kurniawan SN. Meniere 's disease. Journal Pain Headache and Vertigo; 2021. 18-21. DOI: https://doi.org/10.21776/ub.jphv.2021.002.01.5

15. Damayanti R, Welly Dafif M, Nandar Kurniawan S, Munir B, \& Afif Z. Dandy-Walker Variant (DWV) in 70 years old woman with disequilibrium and central vertigo : A case report. JPHV (Journal of Pain, Vertigo and Headache); 2020. 1(1):4-9. DOI: https://doi.org/10.21776/ub.jphv.2020.001.01.2 